\title{
Design and implementation of a preliminar dendromorphical or arborescent key for the identification of the botanical families of the arboreal species of San José de Cúcuta
}

Diseño e implementación de una clave dendromorfa o arborescente preliminar y aplicada para la identificación de las familias botánicas de las especies arbóreas de San José de Cúcuta

Evaristo Carvajal-Valderrama ${ }^{1 *}$

${ }^{I^{*}}$ Especialista en Sistemas de Producción Agropecuaria, evaristoalbertocv@ufps.edu.co, ORCID: 0000-0003-0560-7656, Universidad Francisco de Paula Santander, Cúcuta, Colombia.

How to cite: E. Calvajal-Valderrama, "Design and implementation of a preliminar dendromorphical or arborescent key for the identification of the botanical families of the arboreal species of San José de Cúcuta”. Respuestas, vol. 24, no. 3, pp. 26-30, 2019.

Received on February 10, 2018 - Approved on June 10, 2018

\section{ABSTRACT}

Keywords:

Arborescent,

Native trees,

Urban zone.
The knowledge in biodiversity and the use of botanical terminology is fundamental for ordering and landscape conservation of a city. In San José de Cúcuta, there is no knowledge of tree arboreal species, leading to an inadequate use of trees, triggering inconveniences in electrical networks, aqueducts and sewage systems. The objective of the study was to design and implement an arborescent (or dendromorphic) key as a methodological tool for the identification of native (or naturalised) tree families located in the urban and peri-urban areas of the city of San José Cúcuta. It was considered preferentially the vegetative characteristics and those peculiarities of the plants that are readily observable such as phyllotaxy, the composition and edges of the leaves, the exudate, the presence of spines or aculeos, the presence or absence of glands, pulvinids or stipes, dead bark and live, smells, colors and scores on the sheets, etc. Once the families were identified through the key, a manual was elaborated describing the essential characteristics for their recognition, which includes detailed and panoramic images, as well as excellent morphological descriptions in order to make a comparison to verify if the identifier corresponds to the family found by implementing the use of the arborescent key. By the identification and management of trees, a diversification and appropriate selection of tree species can be established that can make a useful contribution to the physiological, sociological and economic well-being of urban society, contributing to the region's environmental sustainability strategy. The knowledge of tree species is a foundation to guide and define policies towards the landscape planning of the city, aimed at its protection and conservation, as well as the enjoyment of the benefits and ecosystem services provided by the urban vegetation of the city of San José of Cúcuta, recognized nationally as the "Green City of Colombia".

\section{RESUMEN}

Palabras clave: El conocimiento en biodiversidad y el manejo de terminología botánica es fundamental para el ordenamiento y la conservación paisajística de una ciudad. En San José de Cúcuta no existe conocimiento

Arborescentes, Árboles nativos, Zona urbana. de las especies arbóreas, conllevando a un inadecuado uso de los árboles, desencadenando inconvenientes en redes eléctricas, acueducto y alcantarillado. El estudio tuvo como objetivo diseñar e implementar una clave arborescente o dendromorfa como una herramienta metodológica para la identificación de las familias de los árboles nativos o naturalizados ubicados en la zona urbana y peri urbana de la ciudad de San José Cúcuta. Se consideró preferencialmente las características vegetativas y aquellas peculiaridades de las plantas que son fácilmente observables o visibles, tales como la filotaxia, la composición y bordes de las hojas, el exudado, la presencia de espinas o aculeos, la presencia o ausencia de glándulas, pulvínulos o estipulas, corteza muerta y viva, olores, colores y puntuaciones en las hojas, etc. Una vez identificadas las familias a través de la clave, se elaboró un manual donde se describen las características básicas para su reconocimiento, el cual incluye imágenes detalladas y panorámicas, así como descripciones morfológicas sobresalientes con el fin de realizar una comparación para constatar

*Corresponding author

E-mail address: evaristoalbertocv@ufps.edu.co (Evaristo Carvajal Valderrama)

(c) $(1) \Theta$ Peer review is the responsibility of the Universidad Francisco de Paula Santander.

cc) 
si lo identificado corresponde a la familia encontrada implementando el uso de la clave arborescente. Al realizar una identificación y ordenación de los árboles, se puede establecer una diversificación y adecuada selección de especies arbóreas que puedan hacer su aporte efectivo al bienestar fisiológico, sociológico y económico de la sociedad urbana, contribuyendo a la estrategia de sostenibilidad ambiental de la región. El conocimiento de las especies arbóreas es un fundamento para orientar y definir políticas hacia el ordenamiento paisajístico de la ciudad, encaminado a su protección y conservación, así como al disfrute de los beneficios y servicios ecosistémicos que brinda la vegetación urbana de la ciudad de San José de Cúcuta, reconocida nacionalmente como la "Ciudad Verde de Colombia".

\section{Introduction}

The understanding of the biodiversity and particularly of the urban flora is undoubtedly the most valuable support to guide and define policies towards the landscape planning of any city. Due to the above, it is essential to have technical manuals and taxonomic keys (primarily focused on tree plants) that serve as tools for the identification of native or naturalized tree families; which will allow to identify, protect and conserve the arboreal species, and to enjoy to the maximum of the benefits that this type of vegetation offers. The practical application of these tools allows citizens to quickly determine the botanical families of the arboreal species of their region based on the vegetative characteristics and peculiarities of the plants that are readily observable [1].

One of the main characteristics of the dichotomous keys is to allow the characterization of any plant using the smallest number of steps. The above-mentioned is not always possible, and the organization of the pairs of characters can lead to a long process until the identification of a plant at the end of the key is achieved. To use a key, it is necessary to have all the required morphological characters available; otherwise, it will not be possible to advance effectively. A possible solution can be considered if descriptions of more than one character are included in the same dichotomy, but it is not always possible [2], [3] .

Therefore, forestry engineers and taxonomists began to have problems in the identification of tree species, mainly due to the difficulty of finding reproductive organs at a given time; and if they were available, it was challenging to study in the field. Due to the difficulties, it was discovered that each family possesses a particular leaf model (simple, compound, alternate, opposite or verticillated, with stipules or without them, whole edge or sawing, etc.). With these characteristics, the first vegetative keys were established, which were complemented with more field observations such as the type of exudates (latex, gums, resins, mucilage), odours, the location of stipules, the presence of nectaries, type of nerves, composition of the leaves, filotaxis etc [4].

In the city of San José de Cúcuta, there is no knowledge of tree species and their characteristics (such as the type of root system, height, height, branch projection, potential uses, etc.). The latter lead to misuse of different tree species by planting them in unsuitable urban areas where they may cause damage to aqueduct and sewer connections and obstruct electrical networks. Likewise, antitechnical pruning, felling and even destruction of the arboreal vaults existing in the city are carried out. This reflects the need to strengthen the culture of identifying, knowing and describing tree species through the analysis of botanical characteristics through the implementation of an arborescent key as a methodological tool for the identification of botanical families in the city of San José de Cucuta and its metropolitan area.

To achieve the above, the arboreal species of the municipality were identified and categorized by families, a manual of foundation and articulated methodology for the identification of the botanical families was designed and implemented, as well as a technical field file and an application or tutorial to confirm the identification made.

\section{Materials and methods}

\section{Methodology}

The study was carried out as qualitative applied research, through an exploratory and descriptive design with a non-probabilistic analytical component. The work was carried out in three phases: a preliminary followed by a field and a final confirmation phase. 
Preliminary phase. The phase included the following steps:

Elaboration of the guide and methodology for botanical identifi cation: Describes the characteristics of the families of the tree species of San José de Cucuta, with a graphic illustration of the representative organography of each family and the species assigned to every category.

Design and elaboration of a preliminary dendromorphic key Adapted for the families of the trees of San José de Cucuta.

Design and preparation of a preliminary technical sheet for the collection of samples

Design of a tutorial fed with the botanical characteristics of the trees: To facilitate or reaffi $\mathrm{rm}$ the identifi cation or recognition of the family.

Field sampling. This phase consisted of the collection of plant material, preliminary identifi cation, description and taking photographs for each of the species. The preliminary identifi cation was made using the key and the botanical identifi cation guide manual and completing the designed technical sheet [5], [6].

Final con $i$ rmation. With the designed tutorial, the identifi cation made in situ was confi rmed. The tutorial was fed with the analysis and preferential use of the botanical and ecological morphological characteristics of the trees.

Sampling poblation. Arboreal species located in the urban area of the city of San José de Cúcuta and the metropolitan area. The total number was 115 species distributed in 37 botanical families [7].

Instruments and collection techniques. To carry out the study, the following materials were used:

Guide to the foundation and methodology for the identification of families and tree species [8].

Field technical data: Data collection instrument with the characteristics were typifi ed to indicate the identifi cation route. In them, the taxonomic fi le, the description of the selected plant, characteristics of the sample, ecological, silvicultural data, uses, names, etc. were registered.

Collection of samples to analyze inconspicuous details (nectaries, stipules and translucent points) of the specimens and photographic record

Arborescent key template.

The identification was made with the help of a knife, magnifying glass of 10 to 20 magnifications, a deharrowing machine and binoculars.

Specialized keys, books and manuals were also used [9].

\section{Results and Discussions}

Product of the design and implementation of the key could be found that, of the Division Magnoliophyta (old Angiosperma) there are 31 families and 100 species belonging to the class Magnoliopsida (ancient dicotyledon) and 11 species and 3 families: Poaceae, Arecaceae and Musaceae belonging to the Liliopsida Class (monocot) (Figure 1). From the Phyophyta Division (Gymnosperms) there are two families: the Cupressaceae and Araucariaceae and three species belonging to the Coniferopsida Class and one family, the Cicadaceae and one Cica species belonging to the Cycadopsida Class (Figure 1) [10] - [12]. In 1997, through the forestry study of the Colombian Pacific Biogeographic Region, professor and forest engineer Gilberto Emilio Mahecha Vega, designed and implemented as a result of his studio a dendrological key and a manual as an illustrative guide, describing for that region 110 families of dicotyledonous plants and 14 monocotyledonous families. Meanwhile in the present study, an arborescent key was applied only to the urban flora of San José de Cúcuta, describing 31 families of Magnoliopsidas, 3 families of Liliopsidas and 3 families of Pinophitas.
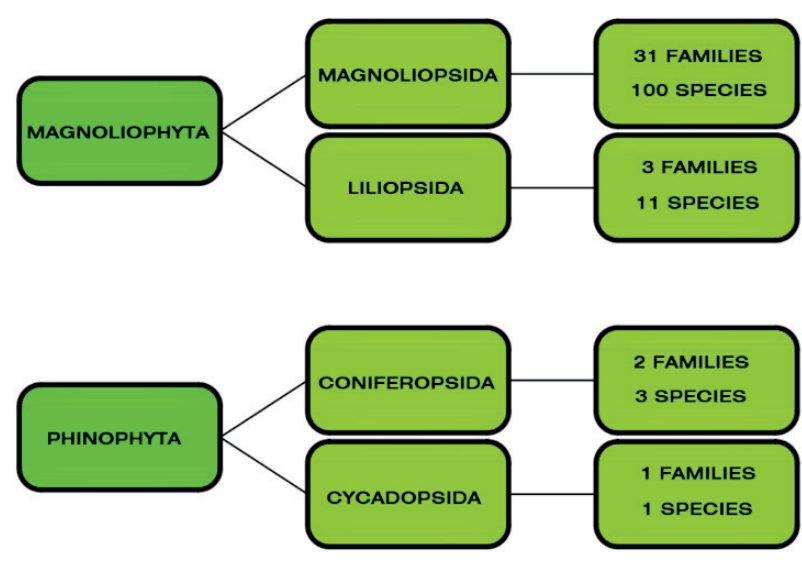

Figure 1. Families and Species description 
Among the results and products obtained in the study are:

Field technical sheets for the collection of information and identification of families (Figure 2).

Templates of preliminary models corresponding to the arborescent key applied to the botanical families of the tree species of San José de Cúcuta (Figure 3).

Manual for the identification of the botanical families of the arboreal species.

Implementation of a tutorial for the confirmation of the identification of families that operates as an automatic password.

Database for the tree species of San José de Cúcuta and its most relevant characteristics.

The results contribute to the knowledge of the arboreal species and their peculiar characteristics to guide the landscaping concerning the arborization of the city.

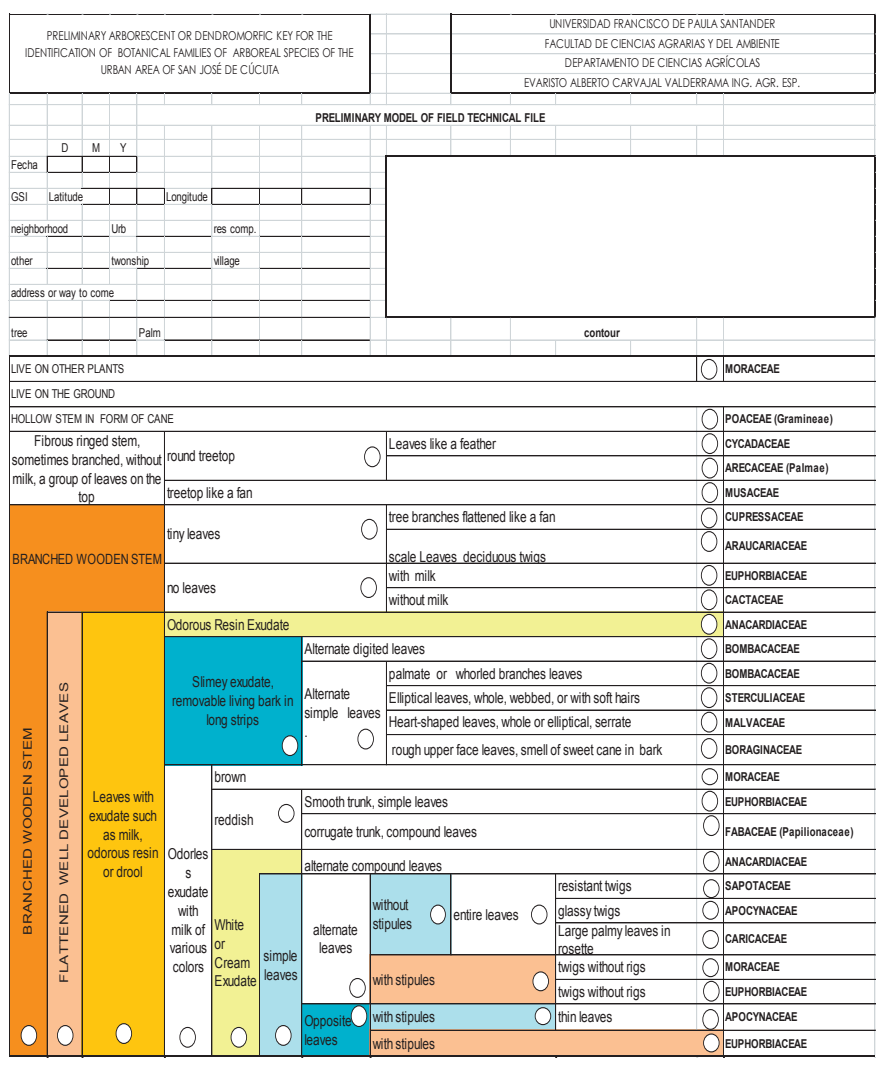

Figure 2. Technical Field datasheet

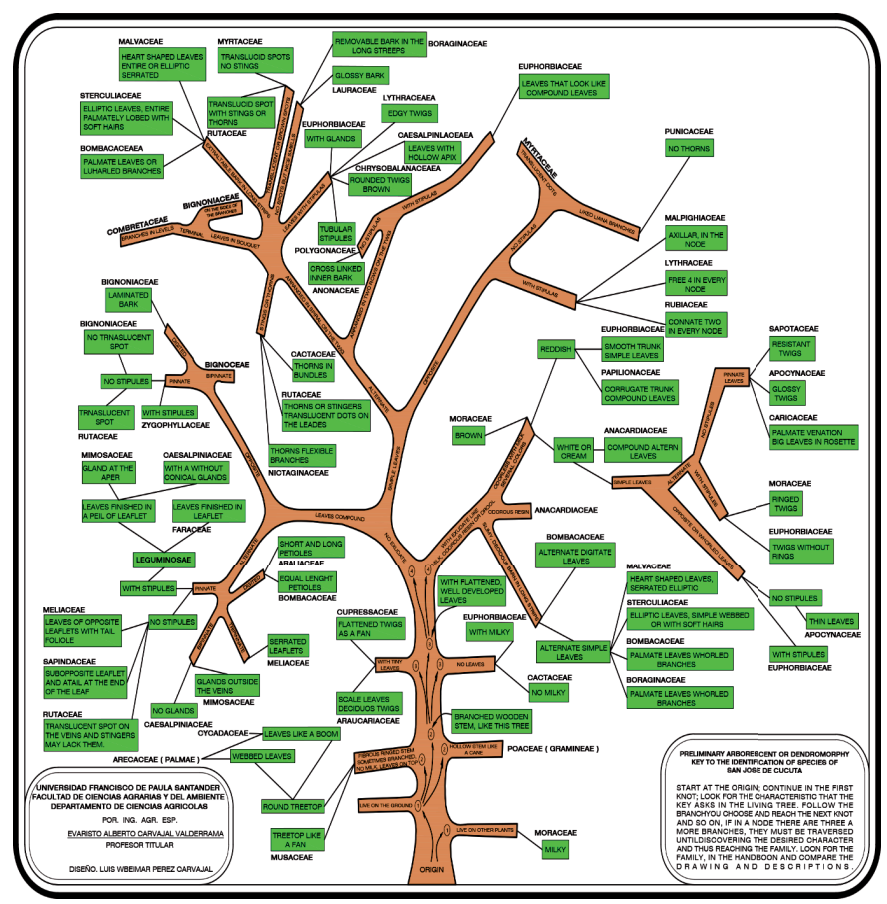

Figure 3. Preliminary arborescent key to the identification of the botanic families of the arboreal species from San José de Cúcuta

\section{Conclusions}

This manual is a tool that contributes to the identification and recognition of the botanical families of the arboreal species (trees, shrubs and palms) and their particular characteristics, which are located in the green areas and different urban spaces that make up the network green road of the city of San José de Cúcuta. The key designed and implemented is a didactic and methodological tool that contributes to the recognition of the families of the arboreal species.

It is recommended to do a work of empowerment in all the educational institutions of the city to generate a culture related to the arboreal knowledge of the species that inhabit the urban environment, using and implementing the educational tools resulting from the study.

\section{References}

[1] J. I. Valle. "Introducción a la Dendrología de Colombia", Universidad Nacional de Colombia, 1972.

[2] E. Escobar and G. De la Cruz, "Claves botánicas. Bogotá”, Universidad Nacional de Colombia, 1981. 
[3] I. Leguizamo, "Clave dendrológica preliminar para los géneros de las Leguminosas colombianas y aplicable a América tropical", Universidad Distrital Francisco José de Caldas, 1978.

[4] T. Lasser, "Clave analítica de las familias. Bogotá", Universidad Nacional de Colombia, 1982.

[5] R. Echeverri and G. Mahecha, "Árboles del Valle del Cauca. Cauca”, Litografía Arco, 1983.

[6] O. Rodríguez and S. Peña, "Flora de los Andes Cien especies del altiplano cundiboyacense", CAR, 1984.

[7] F. Molina. J. Sánchez and M. Gonzáles, "Guía de árboles de Santa Fé de Bogotá. Bogotá", Tercer Milenio, 1995.
[8] G. Galeano, "Las palmas de la Región de Araracuara. Bogotá", Corporación Araracuara, Instituto de Ciencias Naturales, Universidad Nacional de Colombia, 1992.

[9] S. Matteuci and A. Colma, "Metodología para el estudio de la vegetación. Washington, DC", Organización de los Estados Americanos, 1982.

[10] H. García, "Flora medicinal de Colombia: Botánica Médica. Bogotá: Instituto de Ciencias Naturales", Universidad Nacional de Colombia, 1974.

[11] P. Font, "Diccionario de Botánica. Barcelona", Labor, 1977.

[12] J. Almanza, "Botánica Agrícola. Tunja”, Instituto Universitario Juan de Castellanos, 1997. 